\title{
PENGARUH SEDIMEN TERHADAP KAPASITAS TAMPUNG ANAK SUNGAI KARANG MUMUS PADA JALAN WAHID HASYIM KOTA SAMARINDA
}

\section{(THE EFFECT OF SEDIMEN ON THE CAPACITY OF TRIBUTARIES ON THE WAHID HASYIM ROAD SAMARINDA CITY)}

\author{
Yayuk Sri Sundari
}

\author{
Program Studi Teknik Sipil Fakultas Teknik Universitas 17 Agustus 1945 Samarinda \\ Alamat : Jln. Ir. H. Juanda Kotak Pos No.1052 (0541) 743390,761113 Samarinda \\ Email : yayudari@gmail.com
}

Diteima: 30 Maret 2020; Direvisi: 29 Mei 2020; Disetujui:11 Juni 2020

\begin{abstract}
ABSTRAK
Tujuan penelitian ini adalah untuk mengetahui volume sedimen Sungai I dan II Jalan Wahid Hasyim Samarinda. Manfaat penelitian untuk mengetahui volume sedimen anak Sungai, sehingga dapat digunakan untuk mengupayakan optimalisasi fungsi saluran anak Sungai,. Lokasi dan waktu penelitian ini dilakukan pada anak Sungai I dan II Jalan Wahid Hasyim kota Samarinda waktu yang diperlukan dalam penelitian ini selama satu bulan yang meliputi kegiatan studi pustaka, pengumpulan data primer, sekunder, pengolahan, analisis data dan penyusunan penelitian. Obyek penelitian melakukan survai lapangan pada kondisi awal. Dalam analisis sedimen digunakan untuk menentukan angkutan sedimen yang bergradasi. Hasil analisis tanah berdasarkan diameter butiran sedimen dan berat jenis sedimen, hasil analisis angkutan sedimen total untuk seluruh diameter. Sedimen seluruh butiran pada anak Sungai I dan II Jalan Wahid Hasyim kota Samarinda diperoleh $\mathrm{Q}_{\mathrm{B}}=0,0852 \mathrm{~m}^{3} / \mathrm{dt}$ dan $\mathrm{Q}_{\text {rencana }}=102,141 \mathrm{~m}^{3} / \mathrm{dt}>\mathrm{Q}_{\mathrm{awal}}=39,473 \mathrm{~m}^{3} / \mathrm{dt}$ aman pada anak Sungai I Sedimen seluruh butiran pada anak Sungai II Jalan Wahid Hasyim kota Samarinda diperoleh $Q_{B}=$ $0,0345 \mathrm{~m}^{3} / \mathrm{dt}$ dan $\mathrm{Q}_{\text {rencana }}=102,141 \mathrm{~m}^{3} / \mathrm{dt}>\mathrm{Q}_{\text {awa }} \mathrm{l}=39,523 \mathrm{~m}^{3} / \mathrm{dt}$ aman pada anak Sungai II sehingga sedimen yang menyebabkan pendangkalan/sedimentasi dapat mengurangi kapasitas tampung air di anak Sungai. Rekomendasi dari hasil penelitian ini sehubungan dengan adanya potensi kawasan rawan banjir pada anak Sungai tersebut, yang diindikasikan oleh nilai debit banjir maksimum yang melebihi kapasitas saluran anak Sungai, sehingga perlu mengimplementasikan tindakan sipil teknis seperti normalisasi saluran Sungai termasuk jaringan drainase, mengoptimalkan kawasan tampungan air dan daerah resapan air.
\end{abstract}

Kata kunci: analisis tanah, kapasitas saluran, sedimentasi

\begin{abstract}
The purpose of this study was to determine the sediment volume of River I and II at Wahid Hasyim Samarinda. The benefit of research is to find out the volume of sediment tributaries, so that it can be used to work towards optimizing the function of creeks. The location and time of the study was carried out on tributaries I and II at Wahid Hasyim Samarinda city, the time required in this study was one month which included literature study, primary, secondary data collection, processing, data analysis and research compilation. The object of the study is conducting a field survey in the initial conditions. In sediment analysis it is used to determine graded sediment transport. The results of the soil analysis are based on the diameter of the sediment grain and sediment density, the results of the analysis show the total sediment transport for the entire diameter. Sediments All grains in tributaries I and II of Wahid Hasyim road in Samarinda obtained $Q_{B}=0.0852 \mathrm{~m}^{3} / \mathrm{sec}$ and $Q_{\text {plan }}=102,141 \mathrm{~m}^{3} /$ sec $>Q_{\text {early }}=39,473 \mathrm{~m}^{3} / \mathrm{sec}$ safe in creeks of River I Sediment all fractions in tributaries of Wahid road II Hasyim Samarinda city obtained $Q_{B}=0.0345 \mathrm{~m}^{3} / \mathrm{sec}$ and $Q_{\text {plan }}=102.141 \mathrm{~m}^{3} / \mathrm{sec}>Q_{\text {early }}=$ $39.523 \mathrm{~m}^{3}$ / sec safe in creeks II So that this sediment causes siltation / sedimentation which can reduce the water capacity in the tributary. Recommendations from the results of this study relate to
\end{abstract}


Pengaruh Sedimen Terhadap Kapasitas Tampung Anak Sungai Karang Mumus Pada Jalan Wahid Hasyim Kota Samarinda

Yayuk Sri Sundari

the potential offlood prone areas in these tributaries, which is indicated by the value of the maximum flood discharge that exceeds the capacity of the tributary canals, so it is necessary to implement technical civil actions such as normalizing river channels including drainage networks, optimizing water catchment areas and water absorption region.

Keywords: soil analysis, channel capacity, sedimentation

\section{PENDAHULUAN}

Banjir pada daerah sepanjang DAS Karang Mumus dipengaruhi oleh adanya limpasan air permukaan yang relatif besar dan laju tanah yang tererosi sebagai sedimen pada Sungai yang berasal dari daerah tangkapan air di wilayah DAS. Kondisi biofisik sangat mempengaruhi terjadinya banjir dan genangan air pola penggunaan lahan yang salah peruntukan kawasannya dan adanya perubahan tata guna lahan dari daerah resapan air menjadi daerah genangan air, sehingga terjadi peningkatan limpasan permukaan pada DAS tersebut, mempercepat proses terjadinya banjir, jika hujan turun deras dapat meningkatkan laju limpasan air permukaan dan laju sedimentasi. Permasalahan banjir yang sering terjadi disetiap musim penghujan, wilayah Kota selalu tergenang oleh air luapan dari Sungai Karang Mumus. Oleh sebab itu dalam pengendalian banjir Sungai Karang Mumus perlu dilakukan studi mengenai pengendalian banjir Sungai Karang Mumus secara terprogram.

Sungai Karang Mumus merupakan Sungai yang mengalir melalui Kota Samarinda, sebagian besar tebing sungai sudah sangat landai. Pada saat musim penghujan daerah pengaliran Sungai Karang Mumus sering terjadi banjir akibat alur Sungai tidak dapat menampung air banjir dengan sempurna. Pengaruh penutupan lahan/pengunaan lahan terhadap sedimentasi sangat berpengaruh pada saat debit banjir naik karena DAS tidak ada yang menahan maka aliran air permukaan menjadi besar dan terjadi erosi yang berakibat sedimentasi di Sungai sehingga kapasitas Sungai menjadi turun akibat perubahan tata guna lahan terjadi erosi yang berakibat sedimentasi masuk ke Sungai sehingga daya tampung sungai berkurang.

Pengurangan kapasitas aliran sungai dapat disebabkan oleh pengendapan yang berasal dari sedimentasi di Sungai karena tidak adanya vegetasi penutup dan adanya penggunaan lahan yang tidak tepat. Sedimentasi adalah sebagai pengangkutan atau mengendapnya material oleh air dan sedimentasi merupakan akibat dari adanya erosi. Di sungai pengendapan sedimen di dasar Sungai yang menyebabkan naiknya dasar Sungai menyebabkan tingginya muka air sehingga berakibat sering terjadi banjir yang menimpa lahan-lahan yang tidak dilindungi bahwa dua kondisi yang dipenuhi oleh setiap partikel sedimen yang melalui penampang melintang dari suatu Sungai, partikel merupakan hasil erosi di daerah pengaliran di hilir potongan melintang itu dan partikel terbawa oleh aliran.

Tempat erosi terjadi menuju penampang melintang. Kedua kondisi tersebut akan mempengaruhi laju sedimen dalam dua kontrol besaran relatif, kapasitas transport dari saluran dan ketersedian material di Daerah Aliran Sungai. Perubahan penggunaan lahan berpengaruh terhadap penurunan potensi kawasan yang disebabkan oleh semakin meluasnya penggunaan lahan untuk bangunan di sekitar wilayah Kota Samarinda yang menyebabkan pengurangan kawasan resapan air terjadinya genangan atau banjir karena curah hujan jatuh ke permukaan tanah tidak dapat masuk ke saluran air karena tertahan oleh bangunan dan kondisi topografi saluran yang tinggi, saluran tepi jalan yang seharusnya sebagai penangkapan air hujan kurang berfungsi sehingga akan mengganggu transportasi dan bisa merusak badan jalan dan diprediksi akan berpotensi menjadi daerah banjir bila tidak ada penanganan secara dini. Tujuan penelitian ini untuk mengetahui volume sedimen pada saluran anak Sungai I dan II jalan Wahid Hasyim Samarinda. Manfaat dari penelitian ini dapat diketahui volume sedimen anak Sungai, sehingga dapat digunakan untuk mengupayakan optimalisasi fungsi anak sungai akibat sedimentasi. 
Daerah Alliran Sungai mempunyai karakteristik yang spesifik dalam hubungannya dengan jenis tanah, tata guna lahan, topografi, kemiringan dan panjang lereng. Karakter DAS tersebut dapat merespon curah hujan yang jatuh di tempat dapat memberikan pengaruh terhadap besar kecilnya evapotranspirasi, infiltrasi, perlokasi, laju aliran permukaan, aliran permukaan, kandungan air tanah dan aliran Sungai (Asdak, 2010). Topografi seperti kemiringan lahan, kerapatan saluran dan bentuk-bentuk cekungan mempunyai pengaruh pada laju dan volume aliran permukaan (Suripin, 2004). Kemiringan permukaan tanah merupakan salah satu faktor yang berpengaruh terhadap kecepatan limpasan mengalir ke Sungai. Panjang lereng juga berpengaruh terhadap limpasan, semakin panjang lereng pada Daerah Aliran Sungai kecepatan limpasan menuju Sungai semakin lambat, namun tangkapannya lebih besar apabila dibandingkan dengan aliran yang terjadi pada lereng yang pendek atau terjal (Hadisusanto, 2011).

Sedimentasi adalah sebagai pengangkutan atau mengendapnya material oleh air dan sedimentasi merupakan akibat dari adanya erosi. Di sungai pengendapan sedimen di dasar Sungai yang menyebabkan naiknya dasar Sungai menyebabkan tingginya muka air sehingga berakibat sering terjadi banjir yang menimpa lahan-lahan yang tidak dilindungi. Di waduk pengendapan sedimen akan mengurangi volume efektifnya, sebagian besar jumlah sedimen yang dialirkan oleh sungai-sungai yang mengalir ke waduk. Butir-butir yang kasar akan diendapkan di bagian hulu Waduk, sedangkan yang halus diendapkan di dekat bendungan. Sedimentasi merupakan akibat dari adanya erosi dan memberi dampak di Sungai pengendapan sedimen di dasar Sungai yang menyebabkan naiknya dasar sungai, yang menyebabkan tingginya muka air sehingga berakibat sering terjadi banjir. Di Waduk pengendapan sedimen akan mengurangi volume waduk. Butiran yang kasar akan diendapkan di bagian hulu Waduk sedangkan yang halus diendapkan dekat bendungan (Soemarto,1986).

Einstein menyatakan bahwa dua kondisi yang dipenuhi oleh setiap partikel sedimen yang melalui penampang melintang dari suatu Sungai, partikel merupakan hasil erosi di daerah pengaliran di hilir potongan melintang itu dan partikel terbawa oleh aliran dan tempat erosi terjadi menuju penampang melintang itu. Kedua kondisi tersebut akan mempengaruhi laju sedimen dalam dua kontrol besaran relatif, kapasitas transport dari saluran dan ketersedian material di Daerah Aliran Sungai penelurusan banjir adalah prosedur untuk menetapkan waktu dan besarnya aliran pada suatu titik pengamatan yang ditetapkan. Apabila aliran Sungai banjir dasar pertimbangan penelusuran banjir adalah bila terjadi peningkatan debit Sungai, maka volume air yang ada untuk sementara waktu akan tertampung dalam alur sungai pada saat terjadi penurunan debit banjir, jumlah volume air yang sama akan dilepaskan dari penampungannya dan mengakibatkan munculnya gelombang muka air banjir yang bergerak ke hilir Sungai (Hadisusanto, 2011).

Kapasitas tampung air Sungai mempunyai fungsi utama menampung curah hujan setelah aliran permukaan dan mengalirkannya sampai ke Laut, Oleh karena itu sungai dapat diartikan sebagai penampung aliran air yang terbawa dari Daerah Aliran Sungai ke tempat yang lebih rendah dan bermuara ke Laut. Pada saat musim penghujan sering terjadi debit aliran besar terjadi karena daya tampung penampang sungai sudah berkurang akibat sedimentasi (Soewarno,1991). Jika debit dalam saluran meningkat, maka volume penyimpanan saluranpun akan meningkat. Aliran air yang masuk saat banjir pada suatu penampungan akan dilepaskan dengan volume air yang sama pada suatu penyimpanan. Sebagai akibat gelombang banjir pada bagian hilir akan mengalami penurunan (Linsey, 1989 ). Saluran yang paling ekonomis adalah saluran yang dapat melewatkan debit maksimum untuk luas penampang basah, kekasaran, dan kemiringan dasar tertentu. Dari rumus Manning dapat dilihat bahwa untuk kemiringan dasar dan kekasaran tetap, kecepatan maksimum dicapai jika jari-jari hidraulik, R maksimum. Untuk luas penampang tetap, jari-jari hidraulik maksimum jika keliling basah $\mathrm{P}$, minimum, kondisi 
tersebut dapat memberi jalan untuk menentukan dimensi penampang melintang yang ekonomis untuk berbagai macam bentuk, penampang berbentuk trapezium yang ekonomis,luas penampang $\mathrm{A}$, dan keliling basah $\mathrm{P}$ saluran dengan penampang melintang berbentuk trapezium dengan lebar dasar B, kedalaman aliran h dan kemiringan dinding $\mathrm{m}$ (Suripin, 2004).

\section{METODE}

Lokasi dan waktu penelitian dilakukan pada anak Sungai Jalan Wahid Hasyim kota Samarinda waktu yang diperlukan dalam penelitian ini selama satu bulan yang meliputi kegiatan studi pustaka, pengumpulan data primer, sekunder, analisis data dan penyusunan penelitian. Obyek Penelitian dalam kajian ini obyek penelitian anak Sungai Jalan Wahid Hasyim kota Samarinda dan melakukan survai lapangan pada kondisi awal.

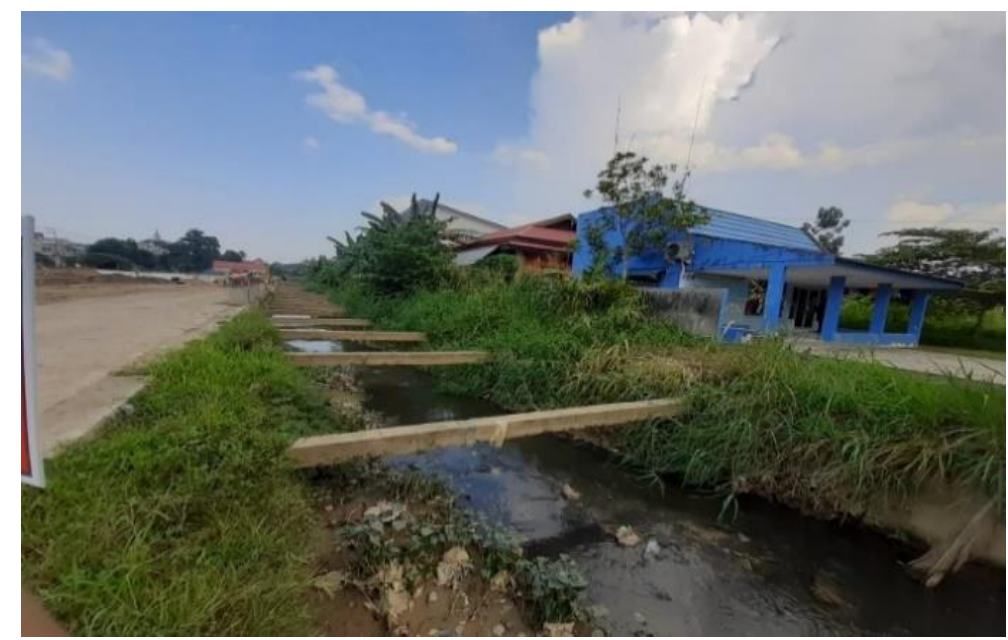

Gambar 1. Kondisi Anak Sungai Jalan Wahid Hasyim Kota Samarinda Sumber: hasil penelitian (2019)

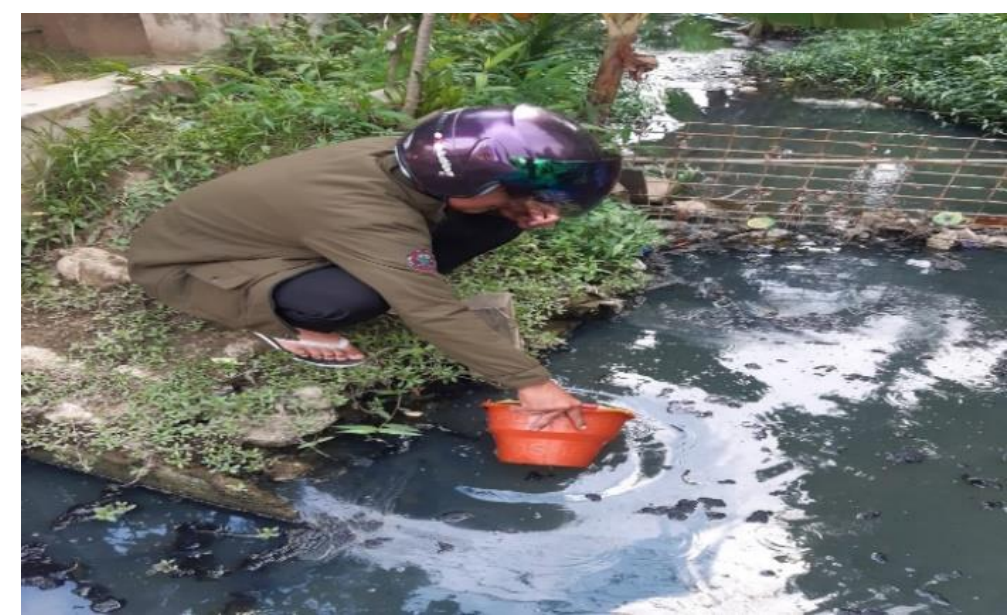

Gambar 2. Pengambilan Sampel Sedimen Pada Anak Sungai II Jalan Wahid Hasyim Kota Samarinda Sumber: hasil penelitian (2019) 


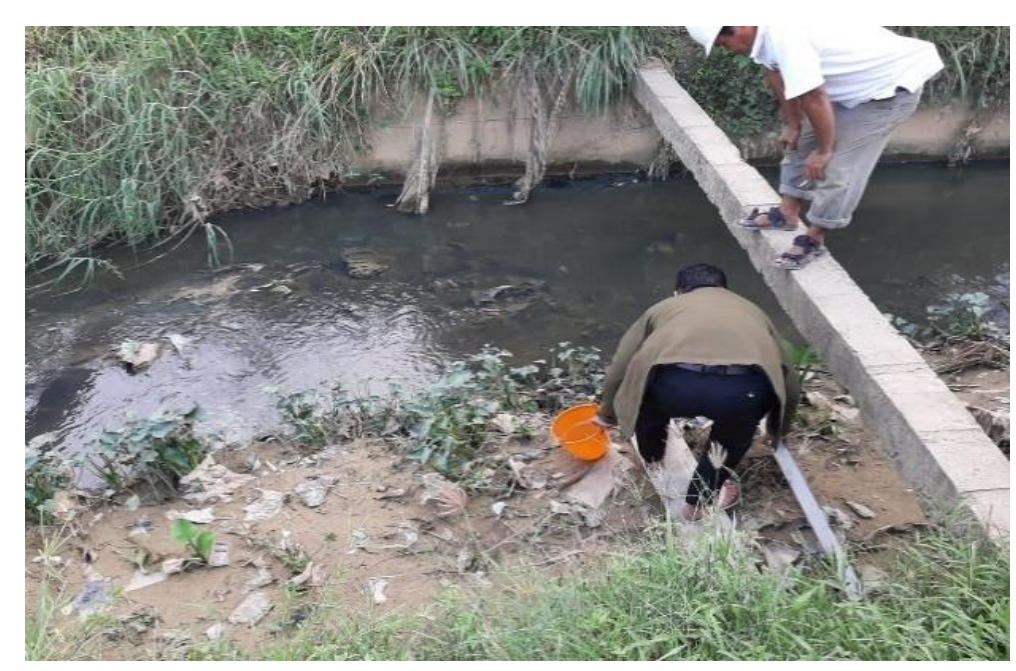

Gambar 3. Pengambilan Sampel Sedimen Anak Sungai II Jalan Wahid Hasyim Kota Samarinda Sumber: hasil penelitian (2019)

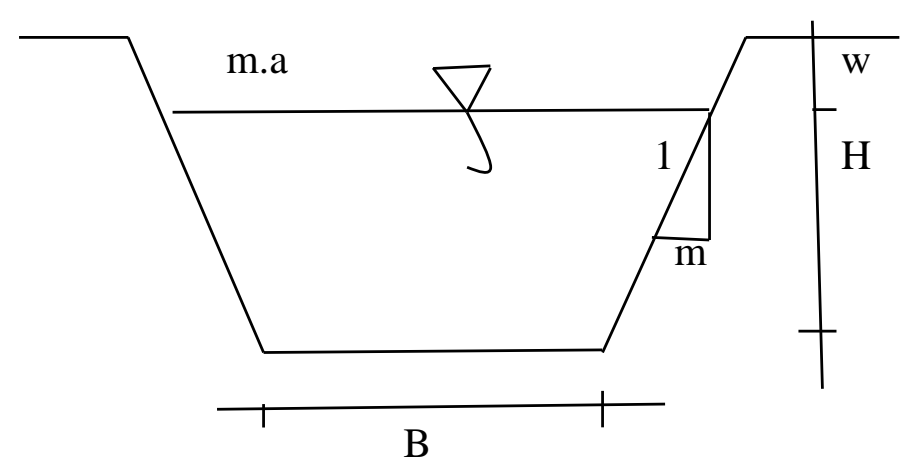

Gambar 4. Penampang Trapesium

Analisis kapasitas tampung air Sungai pada saluran sungai utama diantaranya meliputi:

1. Menentukan kedalaman saluran $(\mathrm{H})$

2. Menentukan lebar saluran ( B)

3. Menentukan kemiringan dasar Sungai yang diijinkan (i)

4. Menentukan koefisien kekasaran Manning (n)

5. Menghitung luas basah :

$$
A=(b+m h) h
$$

6. Menghitung keliling basah:

$$
P=b+2 h \sqrt{m^{2}+1}
$$

7. Menghitung jari-jari hidraulik:

$$
R=\frac{A}{P}
$$

8. Menghitung debit hujan:

$$
\mathrm{Q}=\mathrm{A} \cdot \mathrm{V}
$$

Analisis sedimen dengan menggunakan metode Einstein, persamaan angkutan sedimen dasar dengan metode pendekatan teoritik yaitu teori statistik, metode pendekatan yang digunakan didasarkan pada beberapa konsep yang ditunjang oleh hasil pengamatan 
laboratorium dalam menentukan angkutan sedimen yang bergradasi. Einstein menggunakan D $=\mathrm{D}_{35}$ untuk parameter angkutan sedangkan untuk kekasaran digunakan $\mathrm{D}=\mathrm{D}_{65}$. Hubungan antara kemungkinan butiran akan terangkut dengan intensitas angkutan dasar dijabarkan sebagai berikut.

Persamaan muatan sedimen dasar dengan pendekatan dari Einstein berdasarkan fungsi dari:

$$
\varphi=\mathrm{f}(\psi)
$$

Intensitas muatan sedimen dasar:

$$
\varphi=\frac{\mathrm{q}_{\mathrm{B}}}{\gamma_{\mathrm{s}}} \times \sqrt{\frac{\gamma}{\left(\gamma_{\mathrm{s}}-\gamma\right) \times \mathrm{g} \times \mathrm{D}^{3}}}
$$

Dari pendekatan Einstein

Intensitas aliran:

$$
\begin{aligned}
& \psi=\frac{\gamma_{\mathrm{s}}-\gamma}{\gamma} \times \frac{\mathrm{D}}{\mathrm{S}_{\mathrm{N} \mathrm{R}}} \times 10 \\
& \psi \text { dari grafik Einstein didapat } \varphi
\end{aligned}
$$

Laju muatan sedimen dasar per unit lebar dasar Sungai dihitung dengan rumus:

$$
\varphi=\frac{q_{\mathrm{B}}}{\gamma_{\mathrm{s}}} \times \sqrt{\frac{\gamma}{\left(\gamma_{\mathrm{s}}-\gamma\right) \times \mathrm{g} \times \mathrm{D}^{3}}}
$$

Laju muatan sedimen seluruh lebar dasar Sungai :

$$
\mathrm{Q}_{\mathrm{b}}=\mathrm{q}_{\mathrm{b}} \mathrm{XB}
$$

Hasil analisis tanah diameter butiran, \% butiran sedimen, dan berat jenis sedimen hasil analisis menunjukkan besar angkutan sedimen total untuk seluruh butiran.

Analisis angkutan sedimen dengan menggunakan rumus Einstein diantaranya meliputi:

1. Menghitung intensitas geser pada butir sedimen;

$$
\Psi=\frac{\rho_{\mathrm{s}}-\rho}{\rho} \times \frac{\mathrm{D}}{\mathrm{S} \times \mathrm{R}_{\mathrm{b}}}
$$

Dari gambar grafik Einstein untuk $\psi$ didapat nilai $\varphi$

2. Menghitung intensitas transport pada butir sedimen;

$$
\varphi=\frac{\mathrm{q}_{\mathrm{B}}}{\rho_{\mathrm{s}}} x \sqrt{\frac{\rho}{\left(\rho_{\mathrm{s}}-\rho\right) \times \mathrm{g} \times \mathrm{D}^{3}}}
$$

3. Menghitung laju beban alas $\mathrm{q}_{\mathrm{B}}$;

4. Menghitung berat sedimen persatuan waktu:

$$
\begin{gathered}
\mathrm{Q}_{\mathrm{B}}=\mathrm{Bxq}_{\mathrm{B}}(\mathrm{kg} / \mathrm{dt}) \\
\mathrm{Q}_{\mathrm{B}}=\mathrm{Bxq}_{\mathrm{B}} \mathrm{X}\left(\left(\rho_{\mathrm{s}}-\rho\right)\left(\mathrm{m}^{3} / \mathrm{dt}\right)\right.
\end{gathered}
$$

Keterangan :

$\mathrm{S}=$ kemiringan saluran

$\mathrm{R}_{\mathrm{b}} \quad=$ jari-jari hidrolis $(\mathrm{m})$

$\mathrm{D} \quad=$ diameter butir sedimen $(\mathrm{m})$

B = lebar saluran 


$$
\begin{array}{ll}
\rho_{\mathrm{s}} & =\text { berat jenis sedimen }\left(\mathrm{kg} / \mathrm{m}^{3}\right) \\
\rho_{\psi} & =\text { berat jenis air }\left(\mathrm{kg} / \mathrm{m}^{3}\right) \\
\psi & =\text { intensitas geser pada butir sedimen } \\
\varphi & =\text { intensitas transport pada butir sedimen } \\
\mathrm{q}_{\mathrm{B}} & =\text { laju beban alas }(\mathrm{kg} / \mathrm{mdt}) \\
\mathrm{Q}_{\text {B }} & =\text { berat sedimen per satuan waktu }(\mathrm{kg} / \mathrm{dt})
\end{array}
$$

\section{HASIL DAN PEMBAHASAN}

Dimensi kondisi awal untuk anak Sungai:

$$
\begin{array}{ll}
\mathrm{B} & =3 \mathrm{~m}, \\
\mathrm{H} & =1,5 \mathrm{~m}, \\
\mathrm{~m} & =0,5, \\
\mathrm{n} & =0,025, \\
\mathrm{~S} & =0,03 \\
\mathrm{~A} & =5,625 \mathrm{~m}, \\
\mathrm{P} & =5,5 \mathrm{~m}, \\
\mathrm{R}_{\mathrm{s}} & =1,0227 \mathrm{~m}, \\
\mathrm{~V} & =7,0326 \mathrm{~m}^{2} / \mathrm{dt} \\
\mathrm{Q} & =39,558 \mathrm{~m}^{3} / \mathrm{dt}
\end{array}
$$

Dimensi yang direkomendasikan untuk anak Sungai :

$$
\begin{aligned}
\mathrm{B} & =3 \mathrm{~m} \\
\mathrm{n} & =0,025, \\
\mathrm{~m} & =0,5, \\
\mathrm{H} & =2,5 \mathrm{~m} \text { dan } \\
\mathrm{S} & =0,03 \\
\mathrm{~A} & =10,625 \mathrm{~m}^{2}, \\
\mathrm{P} & =6,5 \mathrm{~m}, \\
\mathrm{R}_{\mathrm{b}} & =1,6346 \mathrm{~m}, \\
\mathrm{~V} & =9,613 \mathrm{~m}^{3} / \mathrm{dt}, \\
\mathrm{Q} & =102,141 \mathrm{~m}^{3} / \mathrm{dt}, \\
\mathrm{T} & =5,5 \mathrm{~m}
\end{aligned}
$$

Kapasitas tampung anak Sungai I yang direkomendasikan sebesar=102,141 $\mathrm{m}^{3} / \mathrm{dt}$, $\mathrm{Q}_{\text {rencan }} \mathrm{a}=102,141 \mathrm{~m}^{3} / \mathrm{dt}>\mathrm{Q}_{\mathrm{awal}}=39,4728 \mathrm{~m}^{3} / \mathrm{dt}$ sehingga kapasitas tampung yang direncanakan aman.

Kapasitas tampung air sungai yang ada lebih kecil dari debit rencana, sehingga dapat diperkirakan saluran tidak mampu untuk menampung volume air yang masuk ke saluran utama, dengan memperbesar dimensi saluran utama khususnya pada bagian ketinggian saluran (h). Perbaikan dengan memperbesar dimensi saluran diharapkan dapat menampung volume air ketika banjir. Kapasitas Tampung air Sungai pengaruh kondisi biofisik terhadap analisis debit banjir pada Sub DAS Karang Mumus, pada topografi/kemiringan lereng berdasarkan peta kemiringan lereng $<8 \%$ kelas kelerengan datar tersebar di daerah sepanjang Sungai. Topografi sangat berpengaruh terhadap genangan banjir, ketinggian kawasan yang lebih rendah dari kawasan disekitarnya seringkali menjadi penghambat laju limpasan permukaan menuju Sungai. Kawasan di pinggiran Sungai merupakan kawasan yang paling rawan banjir apabila terjadi luapan Sungai. Kawasan dengan kemiringan lereng $<8 \%$ adalah kawasan yang sulit menyerap air seperti kawasan pemukiman, lahan dengan perkerasan padat, pertokoan maka semakin rawan banjir. Semakin lambat limpasan permukaannya sehingga terjadi akumulasi aliran 
Pengaruh Sedimen Terhadap Kapasitas Tampung Anak Sungai Karang Mumus Pada Jalan Wahid Hasyim Kota Samarinda

\section{Yayuk Sri Sundari}

permukaan dan menjadi banjir. Topografi sangat berpengaruh terhadap kapasitas tampung sungai atau debit sungai pada sungai utama Karang Mumus.

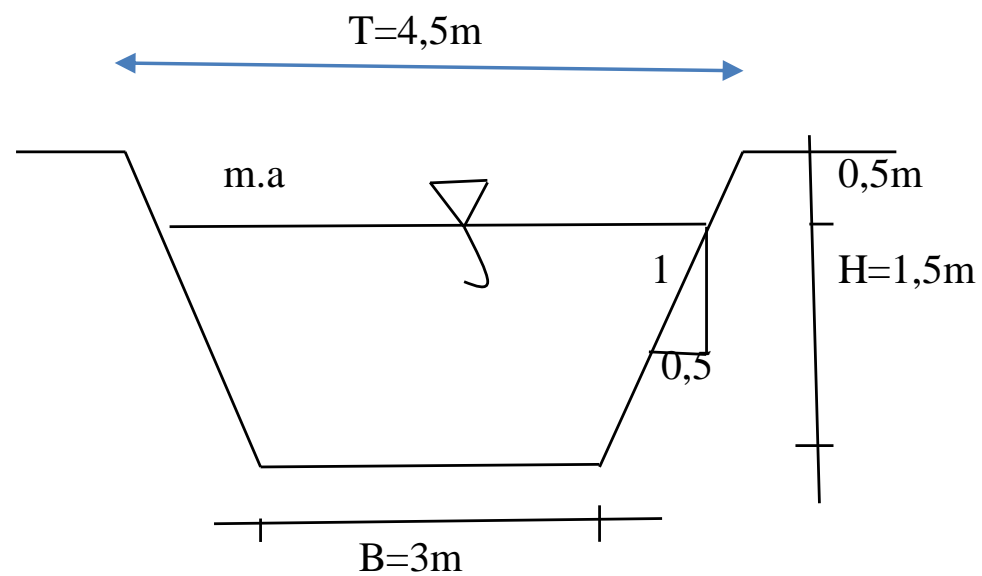

Gambar 5. Kapasitas Tampung Air Sungai kondisi awal Sumber:Hasil Perhitungan (2020)

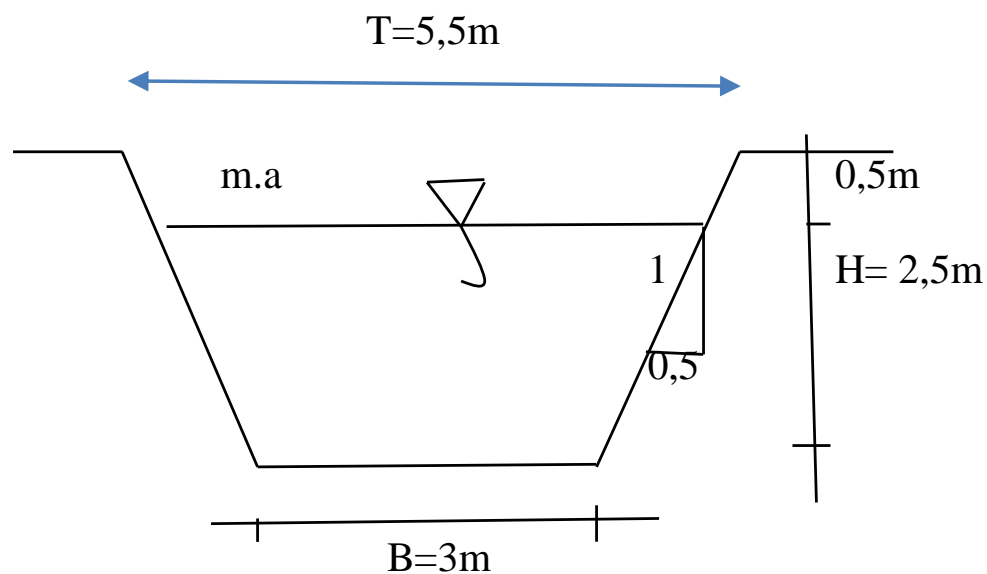

Gambar 6. Kapasitas Tampung Air Sungai yang direncanakan Sumber:Hasil Perhitungan (2020)

Tabel 1. Analisis Tanah Anak Sungai I dan II Jalan Wahid Hasyim Kota Samarinda

\begin{tabular}{|c|c|c|c|c|c|c|c|}
\hline \multirow{2}{*}{ No } & \multirow{2}{*}{ Lokasi Sampel } & \multicolumn{5}{|c|}{ \% Fraksionasi Sedimen Pada Diameter (mm) } & \multirow{2}{*}{$\begin{array}{l}\text { Berat Jenis Sedimen } \gamma_{\mathrm{s}} \\
\qquad\left(\mathrm{kg} / \mathrm{m}^{3}\right)\end{array}$} \\
\hline & & 4,75 & 2,36 & 1,18 & 0,425 & 0,075 & \\
\hline 1 & $\begin{array}{l}\text { Anak Sungai I } \\
\text { Jl.Wahid Hasyim }\end{array}$ & 1,132 & 5,849 & 6,226 & 31,132 & 95,660 & 2589 \\
\hline 2 & $\begin{array}{l}\text { Anak Sungai II } \\
\text { Jl.Wahid Hasyim }\end{array}$ & - & 4,701 & 7,692 & 23,932 & 92,308 & 2532 \\
\hline
\end{tabular}

Sumber: hasil penelitian (2019) 
Analisis angkutan sedimen pada anak Sungai I Jalan Wahid Hasyim kota Samarinda dengan menggunakan metode Einstein adalah sebagai berikut:

$$
\begin{aligned}
\mathrm{S} & =0,03, \\
\mathrm{R}_{\mathrm{b}} & =1,0227 \mathrm{~m} \\
\gamma_{\mathrm{s}} & =2589 \mathrm{~kg} / \mathrm{m}^{3} \\
\mathrm{~g} & =9,81 \mathrm{~m} / \mathrm{dt}^{2} \\
\gamma & =1000 \mathrm{~kg} / \mathrm{m}^{3} \\
\mathrm{~B} & =3 \mathrm{~m}
\end{aligned}
$$

Analisis angkutan sedimen pada anak Sungai II Jalan Wahid Hasyim dengan menggunakan metode Einstein

$$
\begin{aligned}
& \mathrm{S}=0,03, \\
& \mathrm{R}_{\mathrm{b}}=1,0227 \mathrm{~m} \\
& \gamma_{\mathrm{s}}=2532 \mathrm{~kg} / \mathrm{m}^{3} \\
& \mathrm{~g}=9,81 \mathrm{~m} / \mathrm{dt}^{2} \\
& \gamma=1000 \mathrm{~kg} / \mathrm{m}^{3} \\
& \mathrm{~B}=3 \mathrm{~m}
\end{aligned}
$$

Tabel 2. Sedimen Seluruh Fraksi pada Anak Sungai I Jalan Wahid Hasyim Kota Samarinda

\begin{tabular}{cccccccc}
\hline No & $\mathrm{D}(\mathrm{m})$ & $\mathrm{S}$ & $\mathrm{R}$ ( $\mathrm{m})$ & $\psi$ & $\varphi$ & $\mathrm{q}_{\mathrm{B}}(\mathrm{kg} / \mathrm{mdt})$ & $\mathrm{Q}_{\mathrm{B}}\left(\mathrm{m}^{3} / \mathrm{dt}\right)$ \\
\hline 1 & $0,075 \times 10^{-3}$ & 0,03 & 1,0227 & 0,0388 & 0 & 0 & 0 \\
2 & $0,425 \times 10^{-3}$ & 0,03 & 1,0227 & 0,2201 & 9 & 0,8060 & 0,0015 \\
3 & $1,18 \times 10^{-3}$ & 0,03 & 1,0227 & 0,2359 & 9 & 3,7290 & 0,0070 \\
4 & $2,36 \times 10^{-3}$ & 0,03 & 1,0227 & 0,1259 & 9 & 10,5472 & 0,0199 \\
5 & $4,75 \times 10^{-3}$ & 0,03 & 1,0227 & 0,2534 & 9 & 30,1169 & 0,0568 \\
\hline \multicolumn{7}{c}{ Jumlah angkutan sedimen } \\
\hline
\end{tabular}

Sumber: hasil perhitungan (2019)

Kapasitas tampung air anak Sungai kondisi awal sebesar $39,558 \mathrm{~m}^{3} / \mathrm{dt}$ dikurangi 0,0852 $\mathrm{m}^{3} / \mathrm{dt}$ menjadi $39,473 \mathrm{~m}^{3} / \mathrm{dt}$. Kapasitas tampung anak Sungai I yang direkomendasikan sebesar $102,141 \mathrm{~m}^{3} / \mathrm{dt}$, Qrencana $=102,141 \mathrm{~m}^{3} / \mathrm{dt}>$ Qawal $=39,473 \mathrm{~m}^{3} / \mathrm{dt}$ sehingga kapasitas tampung yang direncanakan aman pada anak Sungai I.

Tabel 3. Sedimen Seluruh Fraksi pada Anak Sungai II Jalan Wahid Hasyim Kota Samarinda

\begin{tabular}{cccccccc}
\hline No & $\mathrm{D}(\mathrm{m})$ & $\mathrm{S}$ & $\mathrm{R}_{\mathrm{b}}(\mathrm{m})$ & $\psi$ & $\varphi$ & $\mathrm{q}_{\mathrm{B}}(\mathrm{kg} / \mathrm{mdt})$ & $\mathrm{Q}_{\mathrm{B}}\left(\mathrm{m}^{3} / \mathrm{dt}\right)$ \\
\hline 1 & $0,075 \times 10^{-3}$ & 0,03 & 1,0227 & 0,0374 & 0 & 0 & 0 \\
2 & $0,425 \times 10^{-3}$ & 0,03 & 1,0227 & 0,1933 & 9 & 2,7936 & 0,0055 \\
3 & $1,18 \times 10^{-3}$ & 0,03 & 1,0227 & 0,6641 & 9 & 3,5809 & 0,0070 \\
4 & $2,36 \times 10^{-3}$ & 0,03 & 1,0227 & 1,1785 & 9 & 11,2537 & 0,0220 \\
\hline \multicolumn{8}{c}{ Jumlah angkutan sedimen } \\
\hline
\end{tabular}

Sumber: hasil perhitungan (2019)

Kapasitas tampung air anak Sungai kondisi awal sebesar 39,558 $\mathrm{m}^{3} / \mathrm{dt}$ dikurangi 0,0345 $\mathrm{m}^{3} / \mathrm{dt}$ menjadi $39,523 \mathrm{~m}^{3} / \mathrm{dt}$. Kapasitas tampung anak Sungai II yang direkomendasikan sebesar $102,141 \mathrm{~m}^{3} / \mathrm{dt}$, $\mathrm{Q}_{\text {rencana }}=102,141 \mathrm{~m}^{3} / \mathrm{dt}>\mathrm{Q}_{\text {awal }}=39,523 \mathrm{~m}^{3} / \mathrm{dt}$ sehingga kapasitas tampung yang direncanakan aman pada anak Sungai II. 
Pengaruh Sedimen Terhadap Kapasitas Tampung Anak Sungai Karang Mumus Pada Jalan Wahid Hasyim Kota Samarinda

Yayuk Sri Sundari

\section{KESIMPULAN}

Hasil analisis angkutan sedimen total untuk seluruh butiran $\left(\mathrm{Q}_{\mathrm{B}}\right)$ :

1. Sedimen seluruh butiran pada anak Sungai I Jalan Wahid Hasyim kota Samarinda diperoleh $\mathrm{Q}_{\mathrm{B}}=0,0852 \mathrm{~m}^{3} / \mathrm{dt}$ dan $\mathrm{Qr}_{\text {encana }}=102,141 \mathrm{~m}^{3} / \mathrm{dt}>\mathrm{Q}_{\mathrm{awal}}=39,473 \mathrm{~m}^{3} / \mathrm{dt}$ aman pada anak Sungai I.

2. Sedimen seluruh butiran pada anak Sungai II Jalan Wahid Hasyim kota Samarinda diperoleh $\mathrm{Q}_{\mathrm{B}}=0,0345 \mathrm{~m}^{3} / \mathrm{dt}$ dan $\mathrm{Q}_{\text {rencana }}=102,141 \mathrm{~m}^{3} / \mathrm{dt}>\mathrm{Q}_{\mathrm{awal}}=39,523 \mathrm{~m}^{3} / \mathrm{dt}$ aman pada anak Sungai II.

Sehingga hasil angkutan sedimen ini diduga dapat menimbulkan pendangkalan/sedimentasi yang dapat mengurangi kapasitas tampung air pada anak Sungai tersebut.

\section{REKOMENDASI}

Sehubungan dengan adanya potensi kawasan rawan banjir pada anak Sungai, yang diindikasikan oleh nilai debit banjir maksimum yang melebihi kapasitas saluran anak Sungai tersebut, sehingga perlu mengimplementasikan tindakan sipil teknis seperti normalisasi saluran Sungai termasuk jaringan drainase, mengoptimalkan kawasan tampungan air dan daerah resapan air.

\section{UCAPAN TERIMA KASIH}

1. Editorial Jurnal Riset Pembanguan yang diterbitkan oleh Badan Penelitian dan Pengmbangan Daerah Propinsi Kalimantan Timur.

2. Kepala dan Staf Lembaga Penelitian dan Pengabdian Kepada Masyarakat Universitas 17 Agustus 1945 Samarinda yang telah memberikan dukungan terhadap pelaksanaan kegiatan penelitian.

3. Semua pihak yang tidak dapat disebutkan semuanya yang telah memberikan bantuan baik dukungan moril maupun tenaga.

\section{DAFTAR PUSTAKA}

Asdak, C.(1995). Hidrologi dan Pengolahan Daerah Aliran Sungai. Yogyakarta: Gajah Mada University Press.

Hadisusanto, N. (2011). Aplikasi Hidrologi. Malang: Jogja Mediautama.

Linsley, R.K. and J.B. Franzini. (1989). Teknik Sumber Daya Air. Jakarta: Penerbit Erlangga.

Soemarto, C.D. (1986a). Hidrologi Teknik. Surabaya: Usaha Nasional.

Soemarto, C.D. (1986b). Hidrologi Teknik. Edisi ke 2. Jakarta: Erlangga.

Soewarno. (1991). Hidrologi Pengukuran dan Pengolahan Data Aliran Sungai (Hidrometri). Bandung: Nova.

Suripin. (2004). Sistem Drainase Perkotaan yang Berkelanjutan. Yogyakarta: Andi Offset. 